\title{
The Ethnomatematics and Ethnolinguistics of the Cultural Aimara - Peru
}

\author{
Elena Yucra Yucra ${ }^{1}$, Oscar Mamani Aguilar ${ }^{2}$, and Luis Morales-Aranibar ${ }^{3 *}$ \\ ${ }^{1,3}$ Professor at the National Intercultural University of Quillabamba, Cusco, Peru. \\ ${ }^{2}$ Professor at the Jorge Basadre Grohmann National University, Tacna, Peru.
}

\begin{abstract}
Current research on cultures worldwide has been recovering the knowledge of our ancestors, which has been lost over time and education in the Spanish language does not seek to recover them. The objective of the research is to describe the ethnomathematics and ethnolinguistics of the Aymara culture in the district of Pomata, Puno. The type of research is qualitative-ethnographic. The methodology applied was the interview, survey, participatory observation. Aymara culture currently practices ethnomathematical knowledge to designate the "Jilawi" ages of people, of the time by "Pacha chimpu"; the stars are recognized, the morning star "Qhantati ururi", the Andean new year "Machaqa mara" is celebrated in June, the "Yapuchañanaka" crops; the harvest "Yapu apthapi", ethnogeometry uses it for designs of their houses, marking animals, such as the triangle "Kimsa k'uchu", square "Pusi k'uchu", rectangle "Pusi wiskhalla"; they measure the cereals "phuqthu" by hand, the land by "Yunta". Aymara ethnolinguistics began with the "k'inchu", which were colored threads with knots, and each color had a meaning: white means living in harmony; black mourning and protection; lead property record; coffee registration and marking of animals; They learned to read and write clandestinely, some serving priests, others through military service.
\end{abstract}

\section{1 introduction}

The knowledge of ethnomathematics and ethnolinguistics are developed by indigenous peoples according to their needs, experiences and relationships with the world of which they are part [1]. Ethnomathematics as a science was formulated for the first time by D'Ambrosio in 1984 [1] [2], currently this science has different ways of naming its concept, but none has achieved the acceptance of researchers. Ethnolinguistics was first described by [3] [4] and in his article he associated ethnolinguistics in the Anuario de Letras XIX. These two sciences are related and each culture has its own way of expressing it, and many of them are still valid and others are being lost; If this knowledge is alive, it is because the elderly people still retain it, and share the information with their children, grandchildren, for example the use of some names of animals in the area such as the alpaca, the llama of which They use wool and its different colors; the forms of stones as an accounting tool for their animals [5], among many events that make us think about the use of natural resources that they used in their daily lives and the Peruvian state should not let this knowledge be lost, as many countries like Mexico, Chile, Argentina among others, are recovering their ancestral knowledge as they name it [6] [7] [8] [9].

The Aymara converse with nature, for them all have life and live in harmony with their environment (trees, animals, hills, among others) [10], it is also observed that the inhabitants of the communities define their lands, belongings, changes social, adaptations; information that are essential to understand and characterize different cultures [11] and in this way they can be rescued.

Ethnolinguistics is the relationship of language with the speaking community that links with its own culture [12], where language, culture and society converge, therefore, the object of this science was to articulate the knowledge about their daily lives manifested by their language [13], the Aymara did not know the alphabets of Spanish, in order to save that knowledge and record it in time, they had their own ways of calculating, managing time and space [14].

Currently, this type of work serves to describe and document information in this way to be able to delve into the languages of cultures in academic terms [15]. These types of research have grown in recent years especially in the sociolinguistic field in terms of numbers and attitudes of its speakers [16]. The effects of the inclusion of ethnomathematics and ethnolinguistics are one of the central axes of education, we believe that thinking about the training of indigenous teachers, who teach should be a fundamental proposal in multicultural countries, which will allow the inclusion of policies that protect this knowledge and do not get lost in time [17], this would imply creating new teaching techniques under this

*Correspondencia: luis.morales@uniq.edu.pe 
perspective as [18] which presents a teaching method where characteristic approaches of ethnomathematics are identified, used in the academic world to analyze the observations of the Participants remaining as evidence of their conceptions, similarly [19] describes a pedagogical experience on ethnomathematics that focuses within the pedagogical process, also in studies they describe the experiences and the use of these experiences in their daily lives as they did [20 ] In the south of Chile.

One of the current problems of the Peruvian educational system in the face of Aymara culture, lacks basic studies that allow revaluing it, so there is an immediate need to carry out studies with the aim of contributing to the recovery and development of intercultural education., we question that the ancestral knowledge of Aymara ethnomathematics and ethnolinguistics is currently being gradually lost.

The article rescues the practice of the cultural and linguistic identity of the Aymara, as they do in their studies [21] [22] [23] [24], which raise awareness among academics to revalue and teach children, youth, and adults to to continue practicing, valuing and strengthening their cultural roots, since there is currently a problem that is the massive migration of the youth population out of the areas where they were born, leaving only the elderly population. Therefore, this article opens up researchers to develop more research related to culture at the local, regional, national and international levels.

With the interest of seeking answers from the different studies of the ethnomathematics and ethnolinguistics of Aymara culture, which will contribute to intercultural education at all levels of the educational system, we propose to describe the ethnomathematics and ethnolinguistics of Aymara culture in the district of Pomata, Puno.

\section{Materials and methods}

The research scope was carried out in the province of Chucuito, in the district of Pomata, geographically located in the department of Puno, according to the 2017 census, the district of Pomata has a population of 8544 inhabitants and is located at an altitude of approximately 3824 masl In the present work, 24 people between men and women were taken as a sample, with whom they lived together in order to obtain the information. Bilingual people who understand Spanish and Aymara were selected. Semistructured surveys were applied referring to cultural, agricultural, livestock and commercial activities and who have a good knowledge of Aymara culture [10].

In the research, the ethnographic method was applied with the technique of participatory interview and observation, in order to carry out a qualitative and comprehensive investigation. In the dimension of analysis, the setting or context, description of each activity and systematization of the data sequentially were prioritized [15].

\section{Results and discussion}

\section{Ethnomatematics aimara}

Aymara can determine the age of people from the time they are in the womb to old age, for example the pregnant woman is called "Usuri warmi", they can also determine if the woman is between 4 or 5 months of pregnancy, cataloging it as "Chika usuri", 6 months pregnant as "Tirsu usuri", they can also determine the baby of approximately 8 to 10 months as "P'uru wawa", he drinks from one year to two years as "T'aqa wawa", It has also been shown that they can determine if a boy or girl suffers a biological delay by cataloging it as "Ipi wawa", and they are able to determine when a boy or girl is skilled in their biological development by calling it "Ch'iki wawa".

Also in school age they are called "Yuqalla: boy" and "Imilla: girl", more specifically 6-year-old boys as "Jisk'a yuqalla" and the girl of the same age as "Jisk'a imilla", between the age of 7 to 12 "Jach'a yuqalla: boy" and "Jach'a imilla: girl". The ways of categorizing young people are peculiar due to their physical capacities, abilities, being a leader among other aspects, so the young man is called "Wayna" and the young woman as "Tawaqu", more specifically at 15 to 17 years old. They call " $Q^{\prime} a x u$ wayna: immature male" and "Q'axu tawaqu: immature woman". Those who take religious marriage are called "Chacha / warmi" these people are recognized by the community, in this way they may have some responsibility and they are told "from today onwards you are in the large group" which according to their language is "jichha uruta uksaruxa, jach'a tamanxtawa", we can delve further into table 1.

Table 1. Knowledge of ages from pregnancy to Aymara old age

\begin{tabular}{|c|c|}
\hline Spanish & Aimara \\
\hline One month pregnant & Phaxsi usuri \\
\hline Nine months pregnant & Usuri phuqhata \\
\hline Newborn baby & Asu wawa \\
\hline $\begin{array}{c}\text { The boy or girl from } 3 \text { to } 5 \\
\text { years }\end{array}$ & Irqi wawa \\
\hline The child without parents & Iñu wawa \\
\hline 7 to 12 Years old (Male) & Jach'a yuqalla \\
\hline 7 to 11 years old (female) & Jach'a imilla \\
\hline Young from 18 to 25 years old & Achachi wayna \\
\hline From the marriage & Chacha / warmi \\
\hline $\begin{array}{l}\text { Married adult up to } 50 \text { years } \\
\text { (Male) }\end{array}$ & Chuymani chacha \\
\hline $\begin{array}{l}\text { Married adult up to } 50 \text { years } \\
\text { (Woman) }\end{array}$ & Chuymani warmi \\
\hline
\end{tabular}


The Aymara have their own ways of controlling time, being knowledge that they have inherited from their parents, grandparents over time, animals are a way of guiding themselves, such as the crowing of the rooster or "Wallpa aru" they announce the dawn, and its songs determine the time, in this case there are three songs, the first song indicates that it is 2 am "Nayra wallpa aru / maya wallpa art'a", the second that it is 3 am "Taypi wallpa aru / Paya wallpa art'a" and the third which is 4 am "Qhipa wallpa aru / Kimsa wallpa art' $a$ ". The dawn between 4 to 5 am when it tends to clarify, the Aymara call it "Q'axatatti", they also determine it by the song of the birds who leave their nests to look for food and call it "Willita qhanatati", more knowledge in Table 2.

Table 2: Aymara day and night time measurement

\begin{tabular}{|c|c|}
\hline Spanish & Aimara \\
\hline 6:00 pm. next to dark & Jayp'uthapi \\
\hline 9:00 pm. Bedtime & Ikintaña \\
\hline 12:00 midnight & Chika aruma \\
\hline 02:00 a.m. First crow & nayra wallpa aru / maya \\
\hline of the rooster & wallpa art'a \\
\hline Dawn or new day & Urjti / urutatti \\
\hline 6:00 am. Sunrise & Inti jalsu \\
\hline $\begin{array}{l}\text { 07:00 a.m. Breakfast } \\
\text { time }\end{array}$ & Alwa manq'asiña \\
\hline $\begin{array}{l}\text { 07:00 a.m. Start of } \\
\text { farm work }\end{array}$ & Yapu luraña qallta \\
\hline $\begin{array}{l}\text { 12:00 pm. Break time } \\
\text { and lunch }\end{array}$ & Chika uru \\
\hline $\begin{array}{l}\text { 1:30 p.m. Start of } \\
\text { agricultural activity }\end{array}$ & Jap'utuqiru yapu lurawi qalltaña \\
\hline $\begin{array}{l}\text { 4:30 pm. Pick from } \\
\text { pasture to corral }\end{array}$ & Uywa anakthapi \\
\hline $\begin{array}{l}\text { 5:00 pm. Break after } \\
\text { work }\end{array}$ & Jayp'u samaraña \\
\hline
\end{tabular}

The Aymara settlers demonstrate a wisdom to control the time, as well as the braying of the donkey and the crowing of the rooster, they call it "Chika uru" estimating that it is noon, that is, it is $12: 00 \mathrm{pm}$ to $12: 30 \mathrm{pm}$ This indicates that they should go to eat, it is evidenced that the villager is very strict with their meal times, similarly at 10 in the morning they take a break from their farm work, which they call "Yapu lurañana samarawi".

The Aymara know and observe the stars at night and at dawn table 3 , it is in this way that they control the time generally between 0:00 a.m. to 6:00 a.m.

Table 3. Aymara astronomical knowledge

\begin{tabular}{lr}
\hline \multicolumn{1}{c}{ Spanish } & \multicolumn{1}{c}{ Aimara } \\
\hline Constellation Flame Centaurs & Qawra nayra \\
Oval rectangular shaped stars & Qäna \\
Cross-shaped stars & Kurusa wara wara \\
Evening star & Jayp'u ururi \\
Morning star & Qhantati ururi \\
\hline
\end{tabular}

In the past, the Aymara had tracts of land, they called it "grocery stores" because they had no owner. The Aymara settlers use part of their body such as fingers, feet, arms, or things to be able to measure lengths, since they lacked measuring and writing instruments, an example when they measure $6 \mathrm{~cm}$ this is equivalent to 3 fingers, when they measure from 6 to $8 \mathrm{~cm}$ they join four fingers that they call "Maya t'axlli" or if they measure a fourth, which is the distance between the thumb and the little finger, calling it "Maya chhiya", the arms or strokes use it to measure rivers, roads and terrain, etc. , the measure of a half meter they measure it through the elbow to the tip of the middle finger naming it "Maya mujlli".

Table 4. Aymara calendar

\begin{tabular}{|c|c|}
\hline Spanish & Aimara \\
\hline $\begin{array}{l}\text { Sunday fair day, considered as } \\
\text { the first day of the week (main } \\
\text { fair) }\end{array}$ & Althapi uru \\
\hline Rest day (Saturday) & Samaraña uru \\
\hline The first week of the month & Phaxsi qallta \\
\hline End of the month & Phaxsi tukuva \\
\hline Andean New Year (June) & Machaqa mara \\
\hline Product storage (June and July) & Manq'a apthapi \\
\hline Bean sowing begins (August 1 ) & Sata qallta \\
\hline $\begin{array}{l}\text { Sowing (September, October and } \\
\text { November) }\end{array}$ & Yapuchañanaka \\
\hline Sowing goose & apilla sata \\
\hline Planting quinoa & jiwra phawa \\
\hline Sowing barley & siwara phawa \\
\hline Potato planting & ch'uqi sata \\
\hline $\begin{array}{l}\text { Dry season (November to } \\
\text { December) }\end{array}$ & Awti phaxsi \\
\hline $\begin{array}{l}\text { Rainy season (December to } \\
\text { March) }\end{array}$ & Jallu pacha \\
\hline $\begin{array}{l}\text { Harvest beans, quinoa, barley, } \\
\text { potato, goose (April to May) }\end{array}$ & Yapu apthapi \\
\hline $\begin{array}{l}\text { Cold season making chuño (June } \\
\text { and July) }\end{array}$ & Juyphi pacha \\
\hline
\end{tabular}

In the harvest of tubers, the Aymara keep them in holes of approximately $1.2 \mathrm{~m}$ calling it "Qaxa", they are generally built on the ground, another way to measure the potatoes is in "Phina" that contains 4 arrobas of potatoes, the stem of beans or barley that they gather with their arms they call it "Marqa", and when the rope is used with their arms they know it as "Pichu". The wool of animals such as alpaca, sheep, they process it on a spinning wheel to make the yarn they call it "Qaputa", where the unit is "lluchhu", where a pound is removed 5 conicoidal,

Usually bartering is done at the fairs they attend, the exchange of fruits such as oranges, bananas, breads, matches among other products for their agricultural products that they bring, which have their own ways of measuring for example five wielded with the two Open palms of chuño, quinoa, among others, exchange for a bread to this process they call it "Phuxthu", another way of measuring is wielded with a single palm of the hand, for example, five handfuls of their products exchange it for a banana to this process denominate "Jach'i $i$ ", other forms of measurement are observed in table 5. 
Table 5. Aymara Measurement Forms

\begin{tabular}{cc}
\hline Spanish & Aimara \\
\hline The land distributed by number of & suka \\
furrows & \\
Land of the crop of products is & Yunta \\
measured by & Jarphi \\
Land calculated by seeds & Jach'a wakulla \\
10 drums & Taypi wakulla \\
5 drums & Jisk'a wakulla \\
3 drums & Yuru \\
4 gallons & Jawi \\
Wool equivalent to a pound or half & \\
a pound & \\
\hline
\end{tabular}

The Aymara man uses geometric figures for the construction of his house, markings on animals or in clothing and they are shown in detail in Table 6.

Table 6. Aymara geometry

\begin{tabular}{cc}
\hline Spanish & Aimara \\
\hline Triangle & Kimsa iskina \\
Square & Pusi iskina \\
Rectangle & Pusi iskina wiskhalla \\
Circular shaped ear & K'illpha \\
piercing in cattle & \\
Triangular shaped ear & Llawi \\
pieces in cattle & \\
\hline
\end{tabular}

\section{Ethnolinguistic aimara}

Learning Spanish was forbidden in the Aymara, it was forbidden because the mistis and landowners did not allow it, to add to that that in ancient times there were no basic tools to learn to read and write (paper, pen, ink) that is why people did not know read or write, our study showed that the Aymara could record information through the "K'inchu", being the most important discovery of our work and that this research is only the beginning of more research that we suggest to be given in more depth to revalue and save these ancestral knowledge.

The "K'inchu" consisted of moorings of threads or pitas that contained five or six threads, similar to the "Kipu", they were made of alpaca and llama wool that had different shades table 7 , and that could be evidenced thanks to the replicas of the elderly settlers, generally the "K'inchu" went behind the door of the houses.

Table 7. Meaning of the Aymara "K'inchu" colors

\begin{tabular}{cc}
\hline Colour & Meaning \\
\hline White & Live in tranquility, harmony \\
Black & Grief, mourning, sadness, protection from rain, \\
& frost \\
Lead & Property registration \\
Coffee & Register and mark animals \\
\hline
\end{tabular}

The color black in Aymara culture has many meanings apart from those shown in table 6 , for example when someone assumes the position they have to wear black their entire period to protect their pacha, in this case it has been evidenced that his partner also has to dress in black with the intention of giving prosperity to his population, as well as representing that his family has had a loss of a relative and the time of being in black clothes is from 6 months to a year, this way of life has passed through time and is currently observed. The brown color is used in the marking of animals, it is represented by putting a pita around the neck of your cattle.

The Aymara peasants were mistreated by the mistis who lived in the urban area and knew Spanish. The humiliation and exploitation was mainly due to the fact that the majority were illiterate, being the " beginning for the learning of the illiterate Aymara.

To learn Spanish, the Aymara had to suffer a lot and had to build strategies such as being a servant of the priests where they learned to read and write, another serving the barracks, the priests also recommended children to be educated, in ancient times only there was a school and the only ones who could access were the children of the gamonales or upper class people.

The Aymara settlers in their inscriptions were inspired by their natural resources such as trees, vicuñas, their habitat such as their pampas, hills, their lines express their feelings to protect them as part of their heritage, which expresses their identity.

\section{Conclusion}

The Aymara culture has an important ethnomathematical knowledge, which allowed them to estimate times, seasons and spaces; Using the animals and the stars as indicators, to measure they used their fingers, strokes, they could determine the time of the fetus in pregnancy, the age of the child at 6 years "Jisk'a yuqalla", of the Young from 18 to 25 years "Achachi wayna"; Animals like the rooster are very important because their song announces the dawn "Wallpa aru", when hearing the braying of the donkey and the crowing of the rooster noon "Chika wallpa aru" estimates that they are between 12:00 to $12: 30$ $\mathrm{pm}$, indicating that they should go to eat, they had an important knowledge of the stars, their movement during the night and early morning, they recognize, the evening star "Jayp'u ururi" and the morning star (Venus) "Qhantati ururi", its fairs, seasons and transcendent activities play an important function, through the different months they determine its agricultural calendar. The Andean New Year is called "Machaqa mara" being the month of festivity in June, the sowing of potatoes, beans, oca, quinoa are between September, October and November calling it "Yapuchañanaka", the harvest time of these products between April to May calling it "Yapu apthapi", the lands were distributed by number of furrows "suka", the Chacareo Terrain is measured by "Yunta", the knowledge of geometry was important in their daily life, the triangle they call it "Kimsa k'uchú", squared 
"Pusi k'uchu", rectangle "Pusi wiskhalla", being observed in the construction of their houses, marking of animals or in clothing.

The development of Aymara ethnolinguistics was prohibited by mistis and landowners, there was no paper, pen or ink, however we discovered that if there was a way to record information and it was the "K'inchu", which were made of ties of threads or pitas of colors where each one had its own meaning, the white color means living in tranquility, harmony; the black mourning, sadness, protection from rain, frost; the lead registration of goods and coffee which was to register and mark animals; The mistreatment and humiliation were important situations for learning Spanish, and they suffered a lot to learn it. They had to be servants of priests, serve the barracks, and some were recommended by the same priests so that they could study in schools where only class children could enter High or gamonales, the Aymara were inspired by their natural resources and their environment where they express conservation and their identity.

\section{Acknowledgement}

As a result of the work, we thank the Aymara native inhabitants, who provided us with very valuable firsthand information, recovering the wisdom of the people, as well as the Andean culture researchers, who correctly guided us to the research team. We also thank the native resident Juan Quispe Escobar, for his contributions to the thesis work of the master's degree in ethnomathematics and ethnolinguistics of the inhabitants of the Pomata district and thanks to that work we were motivated to carry out this research article.

\section{References}

1. Peña, P., Tamayo, C., Parra, A. (2015). Una visión latinoamericana de la etnomatemática: tensiones y desafíos. Revista Latinoamericana de Investigación en Matemática Educativa, vol. 18, núm. 2, pp. 137-150.

2. D'Ambrosio. (1985). Socio-cultural Bases for Mathematics Education. Campinas: UNICAMP.

3. Coseriu, Eugenio. (1978). La socio y la etnolingüística. Anuario de Letras XIX, 5-30.

4. Aroca, Armando. (2015). Diseños Prehispánicos, Movimientos y Transformaciones en el Círculo y Formación Inicial de Profesores. Bolema: Boletim de Educação Matemática, 29(52), 528-548.

5. Bermejo Paredes, Saúl, Maquera Maquera, Yanet Amanda, \& Bermejo Gonzáles, Luz Yohana. (2020). Procesos de educación intercultural y autosegregaciónindígena en los aimaras de Puno, Perú. Revista Historia de la Educación Latinoamericana, 22(34), 19-43.
6. Ochoa, R., Peláez, J. (1995). La matemática como elemento de reflexión comunitaria Pueblo Tule. 1. ed. Antioquia: Asociación de Cabildos Indígenas de Antioquia, Editorial Lealon, p.147.

7. Aroca Araújo, Armando. (2014). La lógica de elaboración en los diseños de los platos de las culturas prehispánicas de Nariño. Revista U.D.C.A Actualidad \& Divulgación Científica, 17(2), 587596.

8. Gentil Guegia, Húber Castro Cáliz, Laura Calambás, Arnulfo Guegia, Carlos Alberto Pacho, Edilma Díaz \& Carlos Gueguia. (2012). Matemáticas en el mundo Nasa. Ministerio de Cultura de Colombia, Bogotá.

9. Jaramillo, D., Berrío, L. (2011). Prácticas sociales y prácticas escolares en la escuela indígena: ¿una dialogía posible?. Horizontes, Brasil, v. 29, n. 1, p. 89-99.

10. Apaza Ticona, Jorge, Alanoca Arocutipa, Vicente, Ticona Alacona, Cesario, Calderon Torres, Alfredo, \& Maquera Maquera, Yuselino. (2019). Educación y alimentación en las comunidades aymaras de Puno.Comuni@cción, 10(1),36-46.

11. Aroca, Armando, \& Cauty, André. (2017). Dificultades Metodológicas en la Investigación sobre Pensamiento Matemático Indígena y su Paradójica Educación Matemática. Bolema: Boletim de Educação Matemática, 31(58), 841860.

12. Bartmiński, Jerzy. (2012). Aspects of Cognitive Ethnolinguistic. London: Equinox publishing.

13. Teillier, Fernando. (2015). Configuración de realidad y lengua: bases de una epistemología del mapunzugun. Tesis de Doctorado en Lingüística. Concepción, Chile, Universidad de Concepción.

14. Alanoca Arocutipa, V., Mamani Luque, O., \& Condori Castillo, W. (2019). El significado de la educación para la nación Aymara. Revista Historia De La Educación Latinoamericana, 21(32), 227246.

15. Llanquinao Llanquinao, G., Salamanca Gutiérrez, G., \& Teillier Coronado, F. (2019). Aprendizaje del mapunzugun desde metodologías propias: perspectivas y avances para la revitalización de lenguas originarias. Revista Historia De La Educación Latinoamericana, 21(33). https://doi.org/10.19053/01227238.9918

16. Castro-Inostroza, A., Rodríguez-Nieto, C. A., Aravena-Pacheco, L., Loncomilla-Gallardo, A., \& Pizarro-Cisternas, D. . (2020). Nociones matemáticas evidenciadas en la práctica cotidiana de un carpintero del sur de Chile. Revista Científica, 39(3), 278-295. https://doi.org/10.14483/23448350.16270

17. Osorio, Carolina Tamayo. (2018). Licenciatura en Pedagogía de la Madre Tierra, etnomatemática y formación de profesores. Ciência \& Educação (Bauru), 24(3), 759-777. https://doi.org/10.1590/1516-731320180030014 
18. Albanese, Veronica, \& Perales, Francisco Javier. (2020). Mathematics Conceptions by Teachers from an Ethnomathematical Perspective. Bolema: Boletim de Educação Matemática, 34(66), 1-21. Epub April 17, 2020.https://doi.org/10.1590/1980$4415 \mathrm{v} 34 \mathrm{n} 66 \mathrm{a} 01$

19. Santos, Jorge Alejandro, Bernardi, Lucí dos Santos, \& Nascimento, Márcia. (2020). Algoritmos y sistemas de parentesco: aproximaciones etnomatemáticas en la formación de profesores indígenas. Bolema: Boletim de Educação Matemática, 34(67), 628-650. Epub August 14, 2020.https://doi.org/10.1590/1980-4415v34n67a14

20. Becerril Tello, Merit Nefernefer. (2011). Alcances y limitaciones del método etnográfico aplicado al estudio de la cultura de los grandes simios en cautiverio. Cuicuilco, 18(50), 55-77.

21. Gondim, Diego de Matos. (2020). O trabalho de campo na/para/com Etnomatemática como possibilidade de uma pesquisa afecção: potências do devir. Bolema: Boletim de Educação Matemática, 34(68), 1077-1104. Epub November 30, 2020.https://doi.org/10.1590/19804415v34n68a12

22. Rosa, Milton, \& Orey, Daniel Clark. (2019). Ethnomathematics and the responsible subversion of its pedagogical action: an investigation based on three anthropological approaches. Revista Brasileira de Estudos Pedagógicos, 100(254), 191210. Epub May 16, 2019.https://doi.org/10.24109/21766681.rbep.100i254.3939

23. Martín Camacho, J. (2020). La Etnolingüística como disciplina científica. Propuesta de definición y ámbitos de estudio. Actas do XIII Congreso Internacional de Lingüística Xeral, Vigo 2018, 584-591

24. Sunzuma, Gladys, \& Maharaj, Aneshkumar. (2020). In-service Secondary Teachers' Teaching Approaches and Views Towards Integrating Ethnomathematics Approaches into Geometry Teaching. Bolema: Boletim de Educação Matemática, 34(66), 22-39. Epub April 17, 2020.https://doi.org/10.1590/1980-4415v34n66a02

25. Fernandes, Filipe Santos. (2019). Formação de Professores de Matemática em Licenciaturas em Educação do Campo: entre cartas, epistemologias e currículos. Bolema: Boletim de Educação Matemática, 33(63), 27-44. https://doi.org/10.1590/1980-4415v33n63a02 